\title{
METABOLIC AND CARDIOVASCULAR STUDIES OF PROLONGED INTRAVENOUS ADMINISTRATION OF HUMAN SERUM ALBUMIN
}

\author{
By NICHOLAS S. GIMBEL, CECILIA RIEGEL, AND WILLIAM W. L. GLENN
}

\author{
(From the Harrison Department of Surgical Research, School of Medicine, University of \\ Pennsylvania, Philadelphia, and School of Medicine, Yale University, \\ New Haven, Conn.)
}

(Submitted for publication December 30, 1949; accepted, April 17, 1950)

The fate of transfused plasma proteins has been a subject of investigation for some time. Ten years ago, animal studies showed that homologous plasma proteins were retained during the several days of infusion. There was controversy as to whether or not a subsequent loss of equivalent nitrogen occurred (1-3). Recent studies in Whipple's laboratory (4) have shown, however, that the protein balance of dogs may be maintained for three months with plasma as the sole source of nitrogen. In experiments of this duration, possible storage of portions of the plasma, or lag in its utilization, do not trouble the investigator as they might in briefer experiments.

Studies of the same problem in man have similarly demonstrated the retention of plasma or albumin nitrogen during the early days of administration (5-7). Most investigators have described increased nitrogen output during an after period, which they thought represented catabolism of the protein. Estimates of the portion of plasma protein broken down have varied from $15 \%$ to $80 \%$ (810). Eckhardt and associates (10), administering 37.5 to $75 \mathrm{gm}$ of human serum albumin by vein as the sole source of protein, found positive nitrogen balance in all their subjects. Albumin disappeared from the vascular bed at a rate suggesting that every five days one-half of the remainder of the infused material was being either catabolized or incorporated into protoplasm. Eckhardt emphasized the storage potential of interstitial fluid and lymph.

The purpose of this study was to determine how the healthy human subject disposes of infused albumin. Possible fates for the albumin appeared to be: 1) catabolism to end-products, 2) incorporation into protoplasm, and 3) accumulation in plasma, interstitial fluid, and perhaps within cells.
We planned to give albumin ${ }^{1}$ as the sole source of protein in sufficient dosage and for a sufficient time span to observe its metabolic behavior as storage depots became replete and the subject was faced with an excess. We planned to continue the infusion period if possible until the level of nitrogen output in the urine rose to equal that of the daily parenteral intake, when a steady state would have been achieved. However, we found that cardiovascular complications from albumin accumulation at times forced the termination of the experiment before this condition was fully achieved. In attempting to trace the fate of the infused albumin determinations of urinary potassium, inorganic sulfate, and urea were made. Potassium might be useful because of its association with protoplasm $(2.7 \mathrm{mEq} \mathrm{K}: 1 \mathrm{gm} \mathrm{N})$ (11) while in contrast the albumin which was infused had no associated potassium. Thus, if a constant, low potassium intake was maintained during the intravenous albumin period, changes in the nitrogen: potassium ratio in the urine might serve as an index of the source of the urinary nitrogen. Albumin contains twice as much sulfur (12) as protoplasm or the control milk proteins. Therefore, the ratio of urea nitrogen to inorganic sulfate sulfur (UN/IS) might indicate the proportion of catabolized nitrogen derived from albumin. Urea and inorganic sulfate occupy comparable positions in nitrogen and sulfur metabolism (13); the reproducibility of

\footnotetext{
1 The serum albumin used in this study was processed by the American National Red Cross from blood which it collected from voluntary donors. This is one of a series of investigations on serum albumin being carried out with material supplied by the American National Red Cross. As soon as sufficient data become available to justify final conclusions concerning its therapeutic value a full report to the medical profession on the use of serum albumin in medical practice will be published.
} 
their ratio in the control periods of Experiments II, III, and IV is evidence of their reliability. Urea determinations were also of value because the ratio of urea nitrogen to total non-protein urinary nitrogen (UN/TN) indicated the level of activity of protein metabolic processes.

We estimated the amount of albumin present in the metabolic deadspaces and storage depots represented by plasma, interstitial fluid, and lymph by determining plasma volume, and plasma and lymph protein concentrations. Lymph protein is an approximation of the interstitial fluid protein (14). Cerebrospinal fluid was also studied to see whether albumin penetrated the blood-brain barrier.

For comparison with parenteral administration albumin was taken by mouth during a period in each experiment. Its metabolism following oral feeding roughly approximates what might be expected if fully hydrolysed albumin were given by vein or if intravenously administered albumin were rapidly hydrolysed in the body.

\section{PROCEDURE AND METHODS}

\section{Subjects}

The volunteer subjects, D. F. (aged 30), J. N. (aged 26 ), and M. S. (aged 20) were healthy young men, without previous renal or cardiovascular disease. Two studies were made on D. F. and one each on J. N. and M. S.

\section{Plan of Experiments}

In addition to the period of intravenous albumin administration, each experiment included periods of oral milk protein or pure casein ingestion and of albumin taken by mouth. In two experiments the period of oral milk protein ingestion was repeated.

Experiment I. Subject D. F. $10 / 24 / 47$ to $11 / 25 / 47$.

Period I : eight days in which $32.5 \mathrm{gm}$ protein $(5.2$ $\mathrm{gm} \mathrm{N}$ ) were given daily in the form of whole fresh milk.

Period II: fourteen days in which $35 \mathrm{gm}$ of human serum albumin ( $5.6 \mathrm{gm} \mathrm{N}$ ) were given daily by intravenous infusion.

Period III : seven days in which $35 \mathrm{gm}$ of human serum albumin ( $5.6 \mathrm{gm} \mathrm{N}$ ) were given daily by the oral route.

Experiment II. Subject J. N. 6/14/48 to 7/12/48.

Period I : six days in which $75 \mathrm{gm}$ of skim milk protein $(12 \mathrm{gm} \mathrm{N})^{2}$ were given daily.

Period II : six days in which $75 \mathrm{gm}$ of human serum albumin (12 gm N) were given daily by the oral route.

Period III : six days in which $75 \mathrm{gm}$ of human serum albumin (12 gm $\mathrm{N}$ ) were given daily by the intravenous route.

2 The skim milk powder was kindly provided by the Borden Company.
Period IV : ten days in which 75 gm of skim milk protein (12 gm $\mathrm{N}$ ) were given daily.

Experiment III. Subject D. F. $6 / 25 / 48$ to $7 / 25 / 48$.

Period I : six days in which $75 \mathrm{gm} \mathrm{Labco} \mathrm{casein} \mathrm{(12}$ gm N) were given daily.

Period II : six days in which $50 \mathrm{gm}$ human serum albumin $(8 \mathrm{gm} \mathrm{N})$ were given daily by the oral route.

Period III : seventeen days in which $50 \mathrm{gm}$ of human serum albumin $(8 \mathrm{gm} \mathrm{N})$ were given daily by the intravenous route. On days 8,9 , and 10 , only $25 \mathrm{gm}$ of albumin were given, however.

Experiment IV. Subject M. S. $6 / 19 / 48$ to $7 / 30 / 48$.

Period I: seven days in which $75 \mathrm{gm}$ of skim milk protein (12 $\mathrm{gm} \mathrm{N}$ ) were given daily.

Period II : six days in which $75 \mathrm{gm}$ of human serum albumin (12 $\mathrm{gm} \mathrm{N}$ ) were given daily by the oral route.

Period III : twenty-two days in which $50 \mathrm{gm}$ of human serum albumin $(8 \mathrm{gm} \mathrm{N})$ were given daily by the intravenous route.

Period IV : seven days in which $75 \mathrm{gm}$ of skim milk protein (12 gm $\mathrm{N}$ ) were given daily.

\section{Albumin}

Salt-poor albumin was provided by the American $\mathrm{Na}$ tional Red Cross in $100 \mathrm{cc}$ ampules containing $25 \mathrm{gm}$ of human serum albumin and $1 \mathrm{gm}$ of DL-acetyltryptophane. For infusion these were emptied into flasks containing $1,000 \mathrm{cc}$. of $5 \%$ glucose in water, with variable amounts of sodium chloride. This was done in order to prolong more readily the infusion to one and a half to two hours. The albumin was given in $25 \mathrm{gm}$ doses at the beginning and end of a 10-hour period, except for the subject receiving $75 \mathrm{gm}$ daily, for whom a third infusion was interpolated. The same preparation was used for oral albumin as for intravenous, and feedings were similarly spaced.

\section{Basic Diets}

Experiment I. A non-protein diet, composed of $60 \mathrm{gm}$ of butterfat and sufficient sucrose to afford 2,200 calories, was maintained throughout.

Experiments $I I, I I I$, and $I V$. A diet providing less than $0.5 \mathrm{gm}$ nitrogen daily patterned on that of Eckhardt and colleagues (10) was maintained throughout all periods. It was composed largely of cornstarch, oleomargarine, jelly, and sugar, and provided 3,300 calories daily. The subjects consumed their full rations in all experiments except for the brief lapses of two days each in Experiments II and III noted in the protocols.

A daily multivitamin capsule was provided. Minerals were added to the diet, so that in all Experiments, with the exception of the second period in Experiment II, there was a minimum intake of $10 \mathrm{mEq}$ of potassium, 1.15 $\mathrm{gm}$ calcium, and $0.9 \mathrm{gm}$ phosphorus. The potassium intake during the periods of albumin administration was only sufficient to maintain equilibrium, and because of inevitable renal excretion positive potassium balance was not possible. Sodium chloride intake varied from 0 to $9 \mathrm{gm} \mathrm{a}$ day. 


\section{METHODS OF ANALYSIS}

\section{Specimens}

Urine. 24-hour specimens were collected under toluene. Total nitrogen was determined by a semi-micro Kjeldahl method $(15,16)$; urea by the method of Ormsby (17) ; albumin by precipitation with trichloracetic acid and semi-micro $\mathrm{Kjeldahl}$; inorganic sulfate by benzidine precipitation (18); and potassium by the flame photometer (19) after ignition of specimens.

Feces. Feces were not collected in Experiment I. In Experiments II, III, and IV, specimens were collected in sulfuric acid, each collection representing $1 / 3,1 / 2$, or the whole of a metabolic period. After mixing and suitable dilution, total nitrogen determinations were made by semi-micro Kjeldahl. Potassium in the stool was not determined, but was assumed to be $8 \%$ of the oral intake (11).

Blood. Total nitrogen was determined by semi-micro Kjeldahl method; non-protein nitrogen by the method of Koch and McMeekin (20) ; albumin by the method of Howe (21); urea by the method of Ormsby (17).

Cerebrospinal fluid. Albumin and gamma globulin were determined immunochemically (22) by Dr. Elvin Kabat, of Presbyterian Hospital, New York City.

Lymph. Peripheral lymph was obtained by cannulation of a subcutaneous lymph vessel above the ankle or in the midcalf. To facilitate finding a lymphatic trunk, 0.5 cc. of a mixture of equal parts of Evans T-1824 dye and
$1 \%$ procaine was injected intradermally over the dorsum of the foot. The lymphatic could then be seen as a faint bluish strand. We believe that the fluid examined was lymph and not tissue fluid. When the vessel was cannulated, the subject walked to stimulate lymph flow. Sodium oxalate was used as an anticoagulant. The yields of lymph varied from 0.5 to $2.0 \mathrm{cc}$. The lymph was treated with saturated sodium sulfate to precipitate globulin. The precipitate was filtered off and analysed by the Kjeldahl method. Nitrogen was determined on aliquots of the supernatant fluid by the method of Koch and McMeekin (20).

\section{Cardiovascular Studies}

Plasma volume determinations were made by the Evans dye T-1824 dilution method (23). Subjects were weighed every second morning on a balance accurate to $20 \mathrm{gm}$. Venous pressure determinations were made with a saline manometer. Orthodiagrams and ballistocardiographic tracings were made before, during and after the intravenous albumin periods. Electrocardiograms and chest $x$-rays were made when indicated.

\section{Calculations}

Circulating plasma proteins were obtained from multiplying plasma volume by protein concentrations. Estimation of delayed albumin catabolism during the control period IV following intravenous albumin was made by calculating the "extra" sulfate present in the urine over

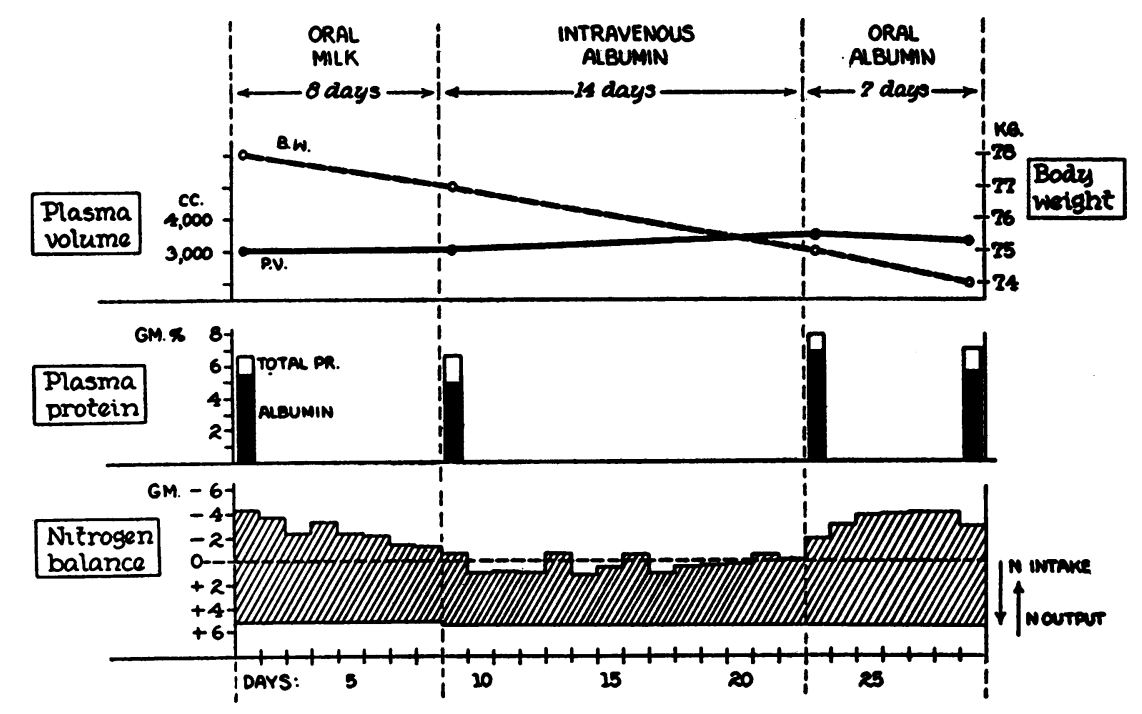

FIG. 1.

Nitrogen balance is shown by the method of Reifenstein (11), in which intake of nitrogen is marked downward from the base line, while output is crosshatched upward from the lowest extent of the intake. Thus a positive balance is shown when crosshatching fails to reach the baseline. Sulfur is similarly shown, except that total sulfur intake is charted against only inorganic sulfate sulfur output. The net potassium balance is shown by a single line to save room in charting. UN/TN per cent refers to the per cent of non-protein urinary nitrogen composed of urea. UN/SO-S refers to the ratio of urea nitrogen divided by inorganic sulfate sulfur. 
TABLE I

Metabolic data

\begin{tabular}{|c|c|c|c|c|c|c|c|c|c|c|c|c|c|c|c|c|c|c|}
\hline \multirow[b]{2}{*}{ Experi- $_{\text {ment }}^{\text {Subject, }}$} & \multirow[b]{2}{*}{$\begin{array}{l}\text { Period and } \\
\text { Subperiod }\end{array}$} & \multirow[b]{2}{*}{ Days } & \multicolumn{3}{|c|}{ Intake } & \multicolumn{6}{|c|}{ Output } & \multicolumn{2}{|c|}{ Balance } & \multicolumn{3}{|c|}{ Ratio } & \multicolumn{2}{|c|}{ Plasma Protein $\S$} \\
\hline & & & $\mathbf{N}$ & $\mathbf{s}$ & $\mathbf{K}$ & $\begin{array}{c}\text { Non- } \\
\text { pro- } \\
\text { tein } \\
\text { Uri- } \\
\text { nary } \\
\mathbf{N}\end{array}$ & $\begin{array}{c}\text { Albu- } \\
\text { min- } \\
\text { uria } \\
\mathrm{N}\end{array}$ & Fecal & Total & $\begin{array}{c}\text { Uri- } \\
\text { nary } \\
-\mathrm{SO}_{4} \\
\text { as S }\end{array}$ & $\mathbf{K}^{*}$ & $\mathbf{N}$ & $\mathbf{K}$ & $\begin{array}{c}\text { Uri- } \\
\text { nary } \\
-\mathrm{SO}_{4,} \\
\text { as S/ } \\
\text { S in- } \\
\text { take }\end{array}$ & $\begin{array}{c}\text { Urea } \\
\text { N/ } \\
\text { Non- } \\
\text { pro- } \\
\text { tein } \\
\text { Uri- } \\
\text { nary } \\
\mathbf{N}\end{array}$ & $\mid \begin{array}{c}\text { Urea } \\
\text { N/:- } \\
\text {-SO. } \\
\text { S }\end{array}$ & $\begin{array}{c}\text { Albu- } \\
\text { min/ } \\
\text { Glob- } \\
\text { ulin } \\
\text { Ratio }\end{array}$ & $\begin{array}{l}\text { Total } \\
\text { Circu- } \\
\text { lating } \\
\text { Plasma } \\
\text { Albumin }\end{array}$ \\
\hline Exp. I ${ }_{\text {D. }}^{\text {I }}$ & $\begin{array}{l}\text { Milk p.o. } \\
\text { Alb. i.v. } \\
\text { Subperiod } 1 \\
\text { Subperiod } 2 \\
\text { Alb. p.o. } \\
\text { After exp. }\end{array}$ & $\begin{array}{c}8 \\
14 \\
2-7 \\
8-14 \\
7 \\
4 \text { th }\end{array}$ & $\begin{array}{l}g m \\
5.1 \\
5.6 \\
5.6 \\
5.6 \\
5.6\end{array}$ & $g m$ & $m E q$ & $\begin{array}{l}g m \\
7.8 \\
5.1 \\
4.8 \\
5.3 \\
9.0\end{array}$ & $\begin{array}{c}g \boldsymbol{g m} \\
\vdots \\
\mathbf{0} \\
\ddagger\end{array}$ & $\stackrel{g m}{\dagger}$ & $\begin{array}{l}g m \\
7.8 \\
5.1 \\
4.8 \\
5.3 \\
9.0\end{array}$ & $g m$ & $m E q$ & $\begin{array}{c}g m \\
-2.7 \\
+0.5 \\
+0.8 \\
+0.3 \\
-3.4\end{array}$ & $m E q$ & $\%$ & $\%$ & & \begin{tabular}{|c|}
$g m \%$ \\
$5.4 / 1.3$ \\
$4.9 / 1.8$ \\
\\
$6.9 / 1.0$ \\
$5.6 / 1.5$
\end{tabular} & $\begin{array}{l}g m \\
163 \\
148 \\
\\
238\end{array}$ \\
\hline $\begin{array}{c}\text { Exp. II } \\
\text { J. N. }\end{array}$ & $\begin{array}{l}\text { Milk p.o. } \\
\text { Alb. p.o. } \\
\text { Alb. i.v. } \\
\text { Milk p.o. } \\
\text { After exp. }\end{array}$ & $\begin{array}{c}6 \\
6 \\
6 \\
10 \\
1 \text { st }\end{array}$ & $\begin{array}{l}12.4 \\
12.4 \\
12.4 \\
12.4\end{array}$ & $\begin{array}{l}0.75 \\
1.47 \\
1.47 \\
0.75\end{array}$ & $\begin{array}{r}90 \\
0 \\
7 \\
92\end{array}$ & $\begin{array}{r}12.3 \\
12.0 \\
5.8 \\
11.2\end{array}$ & $\ddagger$ & $\begin{array}{l}0.8 \\
1.1 \\
1.1 \\
0.4\end{array}$ & $\begin{array}{l}13.1 \\
13.1 \\
6.9 \\
11.6\end{array}$ & $\begin{array}{l}0.67 \\
1.13 \\
0.35 \\
0.66\end{array}$ & $\begin{array}{l}82 \\
26 \\
8 \\
35\end{array}$ & $\begin{array}{l}-0.7 \\
-0.7 \\
+5.5 \\
+0.8\end{array}$ & $\begin{array}{l}+8 \\
-26 \\
+57 \\
+57\end{array}$ & $\begin{array}{l}89 \\
77 \\
24 \\
88\end{array}$ & $\begin{array}{l}86 \\
78 \\
82\end{array}$ & $\begin{array}{l}15.4 \\
9.2 \\
13: 0 \\
14.1\end{array}$ & $\begin{array}{l}5.0 / 1.9 \\
5.4 / 1.6 \\
4.9 / 2.8 \\
6.7 / 1.1 \\
5.7 / 1.7\end{array}$ & $\begin{array}{l}153 \\
181 \\
375 \\
225\end{array}$ \\
\hline $\begin{array}{l}\text { Exp. III } \\
\text { D. F. }\end{array}$ & $\begin{array}{l}\text { Casein p.o. } \\
\text { Alb. p.o. } \\
\text { Alb. i. v. } \\
\text { Subperiod } 1 \\
\text { Subperiod } 2 \\
\text { After exp. }\end{array}$ & $\begin{array}{c}6 \\
6 \\
17 \\
2-8 \\
9-17 \\
1 \text { st } \\
7 \text { th }\end{array}$ & $\begin{array}{r}12.4 \\
8.4 \\
7.7 \\
7.8 \\
7.5\end{array}$ & $\begin{array}{l}0.71 \\
0.98 \\
0.89 \\
0.91 \\
0.87\end{array}$ & $\begin{array}{r}7 \\
13 \\
14 \\
14 \\
14\end{array}$ & \begin{tabular}{r|}
12.6 \\
11.6 \\
4.6 \\
4.4 \\
4.7
\end{tabular} & $\begin{array}{l}\ddagger \\
0 \\
\ddagger\end{array}$ & $\begin{array}{l}0.3 \\
0.8 \\
0.4 \\
0.4 \\
0.4\end{array}$ & \begin{tabular}{|r|}
12.9 \\
12.4 \\
5.0 \\
4.8 \\
5.1
\end{tabular} & $\begin{array}{l}0.73 \\
0.92 \\
0.32 \\
0.25 \\
0.38\end{array}$ & $\begin{array}{r}28 \\
13 \\
8 \\
8 \\
8\end{array}$ & $\begin{array}{l}-0.5 \\
-4.0 \\
+2.7 \\
+3.0 \\
+2.4\end{array}$ & $\begin{array}{r}-21 \\
0 \\
+6 \\
+6 \\
+7\end{array}$ & $\begin{array}{r}103 \\
93 \\
36 \\
27 \\
44\end{array}$ & $\begin{array}{l}88 \\
82 \\
71 \\
63 \\
74\end{array}$ & \begin{tabular}{r|}
15.0 \\
10.4 \\
10.2 \\
10.8 \\
9.2 \\
\end{tabular} & \begin{tabular}{|l|}
$5.2 / 1.7$ \\
$4.9 / 1.7$ \\
$5.3 / 1.4$ \\
$5.3 / 0.9$ \\
$6.7 / 1.2$ \\
$5.4 / 1.8$
\end{tabular} & $\begin{array}{l}224 \\
186 \\
209 \\
281 \\
298 \\
-\end{array}$ \\
\hline $\begin{array}{c}\text { Exp. IV } \\
\text { M. S. }\end{array}$ & $\begin{array}{l}\text { Milk p.o. } \\
\text { Alb. p.o. } \\
\text { Alb. 1.v. } \\
\text { Subperiod } 1 \\
\text { Subperiod } 2 \\
\text { Subperiod } 3 \\
\text { Milk p.o. } \\
\text { After exp. }\end{array}$ & $\begin{array}{c}7 \\
6 \\
22 \\
3-8 \\
9-14 \\
15-20 \\
7 \\
6 \text { th }\end{array}$ & \begin{tabular}{|r|}
12.4 \\
12.4 \\
8.4 \\
8.4 \\
8.4 \\
8.4 \\
12.4
\end{tabular} & $\begin{array}{l}0.75 \\
1.47 \\
0.98 \\
0.98 \\
0.98 \\
0.98 \\
0.75\end{array}$ & $\begin{array}{l}90 \\
10 \\
13 \\
13 \\
13 \\
13 \\
94\end{array}$ & $\begin{array}{r}11.7 \\
13.6 \\
6.7 \\
5.5 \\
6.3 \\
6.9 \\
11.0\end{array}$ & $\begin{array}{l}0.4 \\
0 \\
0.2 \\
0.6 \\
0.4\end{array}$ & $\begin{array}{l}1.8 \\
0.8 \\
0.6 \\
0.6 \\
0.6 \\
0.6 \\
1.3\end{array}$ & \begin{tabular}{|r|}
13.5 \\
14.4 \\
7.7 \\
6.1 \\
7.1 \\
8.1 \\
12.7
\end{tabular} & $\begin{array}{l}0.57 \\
1.33 \\
0.41 \\
0.27 \\
0.45 \\
0.48 \\
0.66\end{array}$ & $\begin{array}{l}97 \\
41 \\
13 \\
13 \\
13 \\
13 \\
\mathbf{3 1}\end{array}$ & $\begin{array}{l}-1.1 \\
-2.0 \\
+0.7 \\
+2.3 \\
+1.3 \\
+0.3 \\
-0.3\end{array}$ & $\begin{array}{r}-7 \\
-31 \\
0 \\
-1 \\
+1 \\
-61 \\
+63\end{array}$ & $\begin{array}{l}76 \\
91 \\
42 \\
27 \\
46 \\
49 \\
88\end{array}$ & $\begin{array}{l}87 \\
92 \\
69 \\
63 \\
81 \\
77 \\
77\end{array}$ & \begin{tabular}{r|}
17.8 \\
9.5 \\
11.9 \\
13.1 \\
11.3 \\
11.0 \\
13.3
\end{tabular} & $\begin{array}{l}5 . \overline{1 / 2.7} \\
4.9 / 1.4\end{array}$ & $\begin{array}{l}\overline{162} \\
147\end{array}$ \\
\hline
\end{tabular}

Note: All data except the plasma protein determinations are presented in the form of daily averages.

* Potassium determinations in the stool were not performed; the stool was presumed to contain $8 \%$ of the oral potassium intake.

t The feces were not analysed for nitrogen in Experiment I.

$\mp$ Albumin was present in the urine by qualitative test, but the amount was too small to influence the calculations.

Albumin/globulin ratios and total circulating plasma albumin figures (albumin concentration $\times$ plasma volume) were determined for the first morning of the period.

and above what would be expected from the control diet:

Urinary $\mathrm{N}$ in control period I

Urinary SO,S in Control period I

$$
=\frac{\text { Urinary (non-protein) } \mathrm{N} \text { in control period IV }}{\text { Expected } \mathrm{SO}_{-} \mathrm{S} \text { in control period IV }}
$$

Then, Actual $\mathrm{SO}_{4}-\mathrm{S}-$ Expected $\mathrm{SO}_{4}-\mathrm{S}=$ "extra" SO-S. The "extra" sulfur is then translated into albumin excretion. Since albumin contains $1.96 \%$ sulfur while body protein and milk protein contain about $1 \%$ sulfur, each gram of albumin catabolized is associated with the excretion of $10 \mathrm{mgm}$ more sulfur than the other proteins would be. Since only $90 \%$ of this will be in the inorganic state, the formula may be written:

Delayed albumin catabolism $(\mathrm{gm})=\frac{\text { "Extra" SO } \mathrm{-S}(\mathrm{gm})}{0.010 \times 0.9}$. Renal Studies

Clearances of inulin and para-aminohippurate and determination of tubular mass with para-aminohippurate were carried out before, during, and after intravenous albumin in Experiments III and IV. Because of the volume of blood drawn for sampling and the possible ef- fect on the metabolic study, equivalent blood transfusions were given after the clearances.

\section{EXPERIMENTS AND RESULTS}

\section{Experiment I}

Clinical data. The period of milk feeding was unremarkable. The period of intravenous albumin passed smoothly ; there were no symptoms of cardiovascular overloading. Plasma volume increased from $3,000 \mathrm{cc}$. to $3,500 \mathrm{cc}$. Hematocrit dropped from $45 \%$ to $39 \%$, indicating either a decrease in red cell mass or a larger plasma volume rise than the dye method showed. A slight albuminuria developed on the eighth day, totalling $1 \mathrm{gm}$ of albumin during the remaining seven days. Faint traces of albuminuria persisted also during the period of oral albumin feeding. At the end of the period of oral albumin feeding, hematocrit had risen to $42 \%$ and plasma volume had fallen to 
$3,300 \mathrm{cc}$. The caloric intake was insufficient, the subject losing $4 \mathrm{Kg}$. at an even rate during the study.

Metabolic data and discussion (Figure 1 and Table $I$ ). During the period of milk feeding, there was a negative nitrogen balance; it was becoming less negative as the period continued.

During the period of intravenous albumin, there was a slight positive nitrogen balance throughout, equivalent to $0.5 \mathrm{gm} \mathrm{N}$ a day, which would doubtless have been reduced to simple equilibrium if feces had been analysed for nitrogen. If the period is reconsidered as two subgroups representing days $2-7$ and $8-14$, a gradual increase in urinary nitrogen is noted. Of the $455 \mathrm{gm}$ of albumin infused, $90 \mathrm{gm}$ may be assigned to the circulatory bed because of the rise in circulating albumin.

During the period of oral albumin, a markedly negative nitrogen balance occurred, the loss averaging $3.4 \mathrm{gm}$ daily. This suggests poor utilization of albumin by mouth, as well as either delayed breakdown of the intravenous albumin or perhaps catabolism of general body protoplasm. It is possible that the nitrogen balance might have been less negative if the subject had been consuming more than 2,200 calories.

Because the subject was free of symptoms of cardiovascular strain, it was planned to double the daily dose of albumin for Experiment II, thereby shortening the time required to fill extracellular depots.

\section{Experiment II}

Clinical data. The periods of milk and of oral albumin feeding were unremarkable. The period of intravenous albumin had an unexpected course. The subject developed a tender liver on the third day, and complained of palpitation. By the fifth day, he had a dry hacking cough and a pounding headache. He had gained $3 \mathrm{Kg}$., while plasma volume rose from $3,350 \mathrm{cc}$. to $5,600 \mathrm{cc}$. Hematocrit fell from $39 \%$ to $33 \%$. Frontal cardiac area as measured by orthodiagram increased $21 \%$ from the control measurement. Resting pulse fell from 60 to 45 beats a minute; blood pressure rose from $115 / 70$ to $130 / 70$. An electrocardiogram showed a tendency towards left axis deviation. Ballistocardiogram showed a decrease of $20 \%$ in cardiac output, although the figure was still within normal range. On the sixth day, optic disks were noted to be slightly blurred. The subject coughed up some rusty sputum, and a chest film showed a pleural reaction at the right base. Dyspnea on exertion and orthopnea were present. The subject was nauseated and could scarcely eat. Albumin had to be stopped immediately, and the final control period begun. The subject was too nauseated to take anything but the skim milk for the next two days. Five days after the cessation of albumin, the marked symptoms of congestive heart failure had regressed. At the conclusion of the experiment, plasma volume fell to $3,950 \mathrm{cc}$., $6 \mathrm{Kg}$. of body weight were lost, and the cardiac

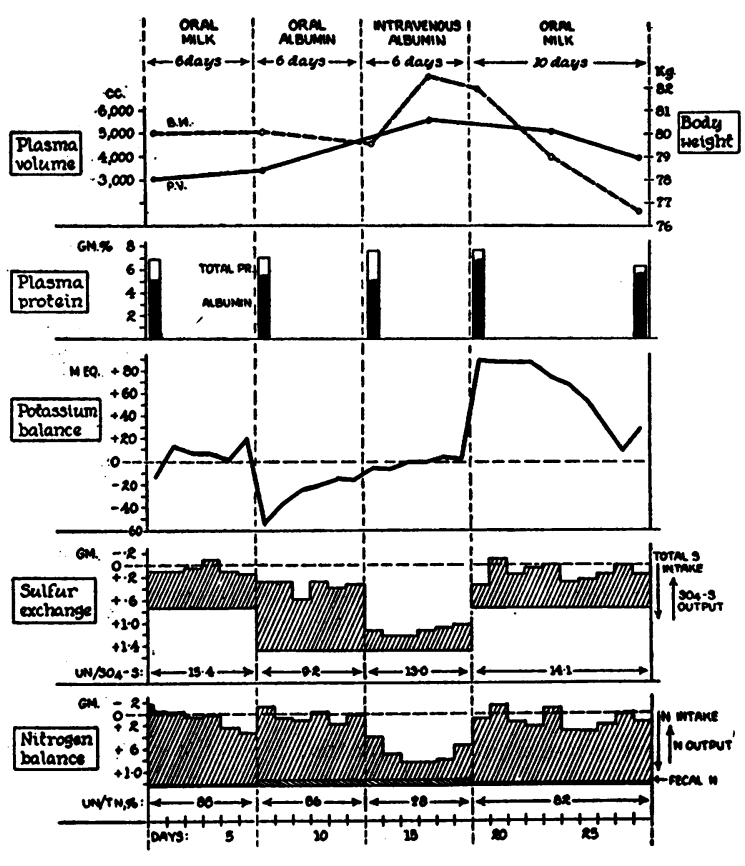

FIG. 2.

See legend for Figure 1.

silhouette returned to its original form. A moderate diarrhea was present for several days of the final period. A trace of albumin was noted in the urine on the second, third, and fourth days of the intravenous period.

Metabolic data and discussion (Figure 2 and Table I). During the period of milk feeding, there was a very slight negative balance. During the period of oral albumin feeding, there was also a very slight negative balance, and in comparison the two appear to be of similar nutritional value.

During the period of intravenous albumin, there was strongly positive nitrogen balance. The low UN/TN ratio indicated the hypometabolism 
of protein in this period. Although relatively little protein was being catabolized, some of this was albumin, as indicated by a UN/IS ratio which was intermediate between those of the milk and the oral albumin periods. A lower UN/IS ratio was present for the last four days of the period than for the overall period, demonstrating that the ratio was not simply the result of a continuing metabolism of the albumin taken by mouth in the preceding period.

During the period of milk feeding at the end of the experiment, there was nitrogen equilibrium. The UN/IS ratio indicated that some albumin was being catabolized together with the milk protein. The urine contained extra inorganic sulfate equivalent to $60 \mathrm{gm}$ of albumin during the 10 day span. Since the subject was in nitrogen equilibrium, $60 \mathrm{gm}$ of milk protein must therefore have been retained. The potassium data are of interest because there was markedly positive potassium balance during the final period, which compensated for the deficit of the oral albumin period when there was no potassium intake, and left the subject with $400 \mathrm{mEq}$ more than he had at the beginning of the study. This gain in potassium is too marked to be explained wholly by an association with protoplasm made from albumin, although it suggests that some albumin had been assimilated into cells. Perhaps there was a generalized retention of cellular water unrelated to protein that would account for the potassium retention.

In accounting for the $450 \mathrm{gm}$ of albumin infused, there was an increase in circulating plasma albumin of $220 \mathrm{gm}$, and 75 to $100 \mathrm{gm}$ were catabolized during the intravenous period. How much of the remaining $150 \mathrm{gm}$ was in the interstitial fluid and how much was synthesized into tissue protein, it is not possible to say.

In Experiment II congestive heart failure made it impossible to continue the intravenous period until massive catabolism of the albumin occurred. However, the sulfate excretion in Periods III and IV is indicative of some albumin catabolism. Over half of the infused material remained as albumin in the metabolic deadspace represented by the plasma and the interstitial fluid. The positive potassium balance suggests that some of the infused albumin was used for tissue synthesis. The experiment was of particular interest in demon- strating that a young man with a normal heart may go into severe congestive failure after receiving amounts of albumin that hypoproteinemic patients commonly accept without difficulty. It was necessary to revise the plans for the subsequent experiments, which were already under way. Fifty gm of albumin a day by vein was chosen as an amount likely to be safe.

\section{Experiment III}

Clinical data. The periods of casein and of oral albumin intake were unremarkable except for a pyrogenic reaction which occurred during a renal clearance study on the first day of the oral albumin period. Accordingly the subject waited two days before recommencing the oral albumin period. In the period of intravenous albumin, body weight increased from the beginning. It was $73.7 \mathrm{Kg}$. at the outset, $74.5 \mathrm{Kg}$. after three days, $75.5 \mathrm{Kg}$. after five days, and $76.9 \mathrm{Kg}$. after seven days. On the seventh day the liver was palpable three fingers' breadth below the costal margin and it was exquisitely tender. Plasma volume had increased from 3,950 to 5,300 , while hematocrit fell from $42 \%$ to $35 \%$. Because of the experience in Experiment II, activity of the subject was reduced, sodium chloride was completely omitted from the diet, and the albumin dosage was reduced to $25 \mathrm{gm}$ daily. After three days at the reduced dosage, $2 \mathrm{Kg}$. body weight were lost, and although the liver remained large, it was less tender. Plasma volume was determined to be 5,800 cc. The dosage of albumin was increased to 50 gm once more. During the remaining seven days, the subject felt moderately ill. Cerebration was slow, euphoria was noted, and there was an occipital headache. The tip of the spleen was palpable. No more than $2 \mathrm{gm}$ of sodium chloride daily was allowed, and activity was somewhat restricted. The blood pressure was elevated to $135 / 85$ from a normal of $120 / 80$. Orthodiagram showed a $25 \%$ increase in frontal cardiac area.

$\mathrm{X}$-ray film of the chest made with a negative pressure of $10 \mathrm{~mm}$ of mercury showed bilateral exaggeration of the lung markings and enlargement of the cardiac silhouette. A second film with $40 \mathrm{~mm}$ of mercury positive pressure showed obliteration of many of these markings in the upper and middle portions of the lung. These were interpreted to show an increased volume of blood in 
the lungs, which was moved out by positive pressure. Ballistocardiographic estimation of cardiac output showed no change over control determinations. Venous pressure was $180 \mathrm{~mm}$ of water, the hepatojugular reflex not being present. Cerebrospinal fluid pressure was $190 \mathrm{~mm}$ of water. A week following the cessation of intravenous albumin, orthodiagram showed a residual $10 \%$ increase in frontal cardiac area still remained. Hematocrit and plasma volume had not appreciably changed. Because of considerable nausea, malaise, and a post-lumbar puncture headache, the subject was unwilling to undergo the control period which had been planned to follow the intravenous albumin.

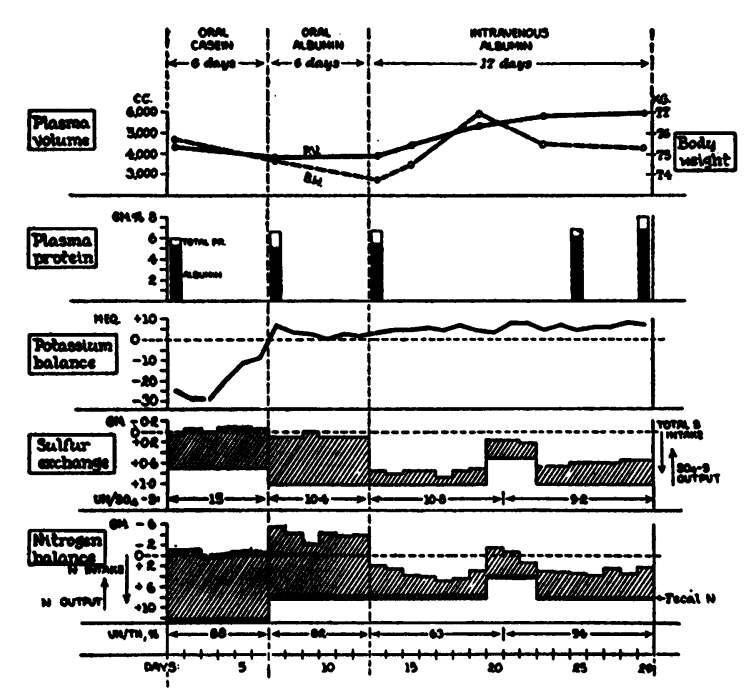

FIG. 3.

See legend for Figure 1.

Metabolic data and discussion (Figure 3 and Table I). During the period of casein feeding, there was a very small negative nitrogen balance.

During the period of oral albumin feeding, a marked negative nitrogen balance occurred, though not so great as during the period of oral albumin in D. F.'s first experiment. Inspection of the sulfur output is useful here in discriminating between a negative nitrogen balance resulting from poor utilization of the albumin, and one that was the result of the induction of a breakdown of the subject's other tissues. The latter would have been associated with the retention of considerable albumin sulfur, and therefore a positive sulfur balance in the face of a negative nitrogen balance. How- ever, the urine contained an amount of inorganic sulfate equivalent to $93 \%$ of the ingested albumin sulfur. We therefore believe that it was the poor utilization of the albumin which was primarily responsible for the negative balance.

During the period of intravenous albumin, there was strongly positive nitrogen balance. Over 2 gm of nitrogen were retained daily, and urinary nitrogen was, in fact, less than during the intravenous albumin period of Experiment I, when less albumin was infused. The low UN/TN ratio indicated that little protein was being catabolized. The urine inorganic sulfate was equivalent to only $35 \%$ of the infused albumin sulfur. However, although the total amount of protein undergoing catabolism was relatively small, a substantial proportion of it was albumin. The UN/IS ratio was 15.0 in Period I and 10.4 in Period II. In Period III, it was 10.2. A more dynamic picture of Period III is obtained if it is divided into two subperiods, represented by days $2-8$ and $9-17$. This analysis adduced evidence of increasing catabolism of albumin in the second subperiod. While the total nitrogen output was essentially unchanged, the UN rose, and the inorganic sulfate excretion increased considerably. The increase in average daily IS excretion of $135 \mathrm{mgm}$ represented an increase in the daily catabolism of $12 \mathrm{gm}$ of albumin. Corroborative evidence that the increase in catabolism was of the albumin rather than of the body tissues themselves is furnished by the ratio of potassium to total nitrogen in the urine, which fell from 1.8 to 1.4 , rather than increasing as would be expected with protoplasmic breakdown.

Evidence for the inert accumulation of much of the albumin which has not been catabolized is presented by the circulatory embarrassment, and the increase in circulating albumin of $75 \mathrm{gm}$. A specimen of peripheral lymph collected on the last day of Period III showed an albumin concentration of $4.6 \mathrm{gm} \%$, with a total protein of $4.8 \mathrm{gm}$ $\%$. These determinations suggest that the accumulation of albumin in the interstitial fluid and lymph was of the order of 200 to $400 \mathrm{gm}$, at the conclusion of the intravenous albumin period. Thus, of the $775 \mathrm{gm}$ of albumin infused, approximately $50 \%$ was still present in the plasma and interstitial fluid when the experiment ended. The amount of albumin catabolized is estimated to be 100 to $200 \mathrm{gm}$. There remain about $200 \mathrm{gm}$ of 
albumin not allocated, which also may have been in the interstitial fluid, or which may have been converted into protoplasm.

\section{Experiment IV}

Clinical data. The period of skim milk feeding was unremarkable except for mild diarrhea. The period of oral albumin ingestion was unremarkable except for a pyrogenic reaction in the course of a renal clearance study on the fourth day. The period of intravenous albumin was undergone with considerably fewer symptoms than in the preceding two experiments. On the tenth day, although there were no symptoms of heart failure, plasma volume had increased from $3,000 \mathrm{cc}$. to $4,300 \mathrm{cc}$., and the hematocrit fell from $45 \%$ to $39 \%$. Frontal cardiac area increased $25 \%$ over the initial measurement. There was no change in body weight. After 20 days of intravenous albumin, the subject had a mild sense of palpitation, felt weak, and had some dyspnea on climbing steps. The liver edge was just palpable. Blood pressure had risen from $125 / 80$ to $150 / 80$, and resting pulse rose from 80 to 100 per minute. Venous pressure was $150 \mathrm{~mm}$ of water. Ballistocardiograph showed no change in cardiac output over the control. Plasma volume was $4,550 \mathrm{cc}$., with hematocrit of $40 \%$. Body weight was $1.3 \mathrm{Kg}$. less than at the onset of the pe- riod. During the last two weeks of the intravenous period, a progressive albuminuria developed, on the last day, $6.3 \mathrm{gm}$ of protein being excreted. During the period of skim milk feeding which followed, the subject continued to feel weak. Plasma volume was still $4,300 \mathrm{cc}$. ten days after cessation of albumin administration, but hematocrit had risen to $42 \%$. Orthodiagram showed $20 \%$ increase in frontal cardiac area. The albuminuria gradually decreased, but was still present nine days after the last intravenous infusion.

Metabolic data and discussion (Figure 4 and Table I). During the period of skim milk feeding, there was a slight negative balance; this was partly due to diarrhea.

During the period of oral albumin feeding, there was a negative nitrogen balance of $2 \mathrm{gm}$ daily, despite normal stool nitrogen content. As in Experiment III, the urinary inorganic sulfate was high, equivalent to $91 \%$ of the albumin sulfur ingested.

During the period of intravenous albumin feeding, there was nitrogen equilibrium. However, this overall computation does not give a meaningful representation of the subject's course. One may suppose the first two days to show an influence from the continuing metabolism of the preceding higher protein intake. During the last two

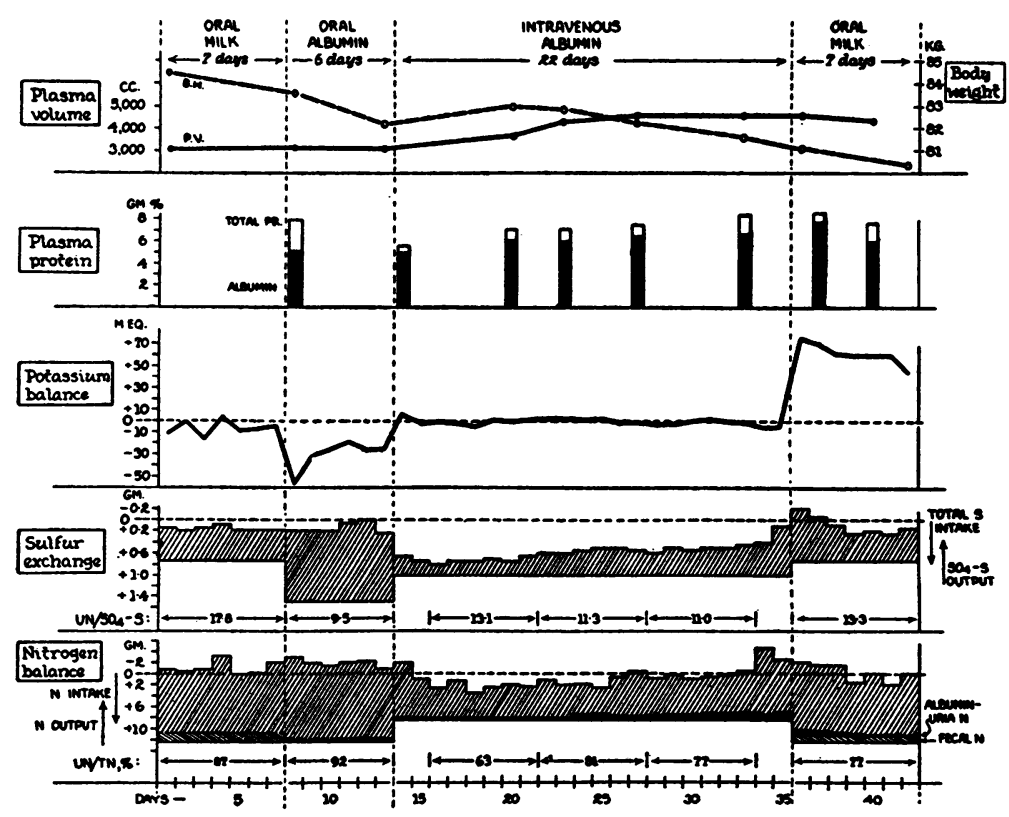

FIG. 4.

See legend for Figure 1. 
days, there was a marked increase in nitrogen, which is unexplained; there was no accompanying rise in urea or sulfate output. If the remaining 18 days of the period are divided into three sixday subperiods, a progressive catabolism of albumin is demonstrated. Comparison of first and third subperiods shows that average daily nonprotein urinary nitrogen output increased from $5.5 \mathrm{gm}$ to $6.9 \mathrm{gm}$, and UN/TN from 0.63 to 0.77 . Average daily inorganic sulfur excretion rose from $27 \%$ to $49 \%$ of the daily albumin sulfur intake, while UN/IS decreased. The subject was in potassium equilibrium during the intravenous period; positive balance was impossible because of the minimal intake and inevitable renal excretion. This balance suggests that albumin was the major source of the urinary nitrogen. If the nitrogen in the urine during the three subperiods were derived from breakdown of the subject's tissues, a daily potassium deficit of $17 \mathrm{mEq}$ should have occurred.

During the period of skim milk feeding that followed, the subject was in approximate nitrogen equilibrium, the slight deficit being the result of a persistent proteinuria. There is evidence of continued albumin catabolism in this period ; the UN/ IS ratio is 13.3 , well below the ratio of $17.8 \mathrm{ob}-$ tained during Period I. For the seven days, the urine contained $0.86 \mathrm{gm}$ of additional sulfate over and above what should be excreted if only skim milk or protoplasm were being metabolized. This indicates that approximately $90 \mathrm{gm}$ of albumin were catabolized. The nitrogen equilibrium of this period, therefore, represents a resultant retention of milk protein and excretion of albumin. The potassium balance in Period IV, similar to that in Experiment II, was very markedly positive, 435 $\mathrm{mEq}$ being retained. Even if most of the loss of $185 \mathrm{mEq}$ of potassium in Period II required direct replacement, one still has an uptake of 250 $\mathrm{mEq}$ of potassium to account for. In the stoichiometric ratio of $2.7 \mathrm{mEq}$ potassium : $1 \mathrm{gm}$ nitrogen, this should be associated with the retention of 550 $\mathrm{gm}$ of protein. Since approximately $90 \mathrm{gm}$ of milk protein were retained during Period IV, the calculation suggests that $450 \mathrm{gm}$ of albumin were synthesized into tissue protein. Little significance is attached to this computation, however, because chronic albumin administration may produce an increase in cellular water, and perhaps therefore potassium retention.
There is evidence also for the accumulation of considerable amounts of albumin during the intravenous period. Circulating plasma albumin increased by $170 \mathrm{gm}$. A lymph collection at the time showed a protein concentration of $4.5 \mathrm{gm} \%$, albumin being $3.9 \mathrm{gm} \%$. A second cannulation a week later showed no change. A control determination had not been done. It is apparent, however, that 200 to $400 \mathrm{gm}$ of albumin may well collect in the interstitial fluid. Thus, when one comes to account for the $1,100 \mathrm{gm}$ of albumin on the last day of intravenous administration, the following allocation presents itself:

\begin{tabular}{|c|c|}
\hline $\begin{array}{l}\text { Albuminuria } \\
\text { Increase in plasma albumin } \\
\text { Present in interstitial fluid } \\
\text { Catabolized to urea, etc. } \\
\text { Synthesized into tissue protein }\end{array}$ & $\begin{array}{l}50 \mathrm{gm} \\
170 \mathrm{gm} \\
200-400 \mathrm{gm} \\
300-400 \mathrm{gm} \\
?\end{array}$ \\
\hline
\end{tabular}

Inferences from the potassium retention are not considered reliable enough to be confident that albumin has been incorporated into protoplasm. The albumin unaccounted for might also be in the interstitial fluid.

\section{GENERAL DISCUSSION}

Prior to carrying out these experiments, we supposed that if parenteral serum albumin were metabolized even in small amounts, and if parenteral albumin administration were maintained long enough, the urinary excretion of nitrogen should eventually increase to the point of approximate nitrogen equilibrium. This state appears to have been achieved during the 14th to 20th days of albumin administration in Experiment IV. The proportion of infused sulfur excreted as inorganic sulfate did not rise as high as would be predicted from the nitrogen excretion. The reason for the relative retention of sulfur is unknown. Subject D. F. in the last days of Experiment I was also in equilibrium. In the 60- and 90-day infusion studies of Terry and associates (4) one notes that in both experiments, dog 43-346 needed 12 to 16 days before urinary nitrogen excretion rose to the range of plasma protein nitrogen intake. This lag is confirmed in our subjects. Cardiovascular complications prevented Experiments II and III of J. N. and D. F. from arriving at equilibrium. It is obvious that the administration of albumin 
to normal subjects brings about a highly unnatural physiological state. J. N.'s plasma volume increased by $85 \%$, and he was in severe congestive heart failure; D. F.'s plasma volume increased by $50 \%$, and he was in moderate congestive heart failure. It is a puzzle that D. F. had no cardiovascular strain in Experiment I but was in considerable difficulty in Experiment III, when only $15 \mathrm{gm}$ more albumin were given daily. $\mathrm{He}$ appears to have catabolized albumin more rapidly in Experiment I. Other possible factors are that Experiment III was in progress during a hot summer month, and that the subject had to be much more active during this experiment.

There were many signs of albumin accumulation, in addition to that in the plasma. The peripheral lymph albumin concentration was $3.9 \mathrm{gm} \%$ in Experiment IV ; in Experiment III, it was 4.6 gm $\%$, with a control determination $3.2 \mathrm{gm} \%$ made nine months after the experiment. The fact that the control lymph protein was so much higher than the figure of $0.5 \mathrm{gm} \%$ given by Drinker (14) for normal human peripheral lymph, we attributed to the vigorous walking used in stimulating lymph flow. The lymph concentrations substantiate Eckhardt and colleagues (10) in their postulate of extravascular accumulation of albumin. The albuminuria developed especially by M. S. has commonly been noted in subjects with normal kidneys (24). Cerebrospinal fluid specimens, obtained from M. S. and D. F. on the final day of their intravenous periods, showed a small increase in total protein; the increase in the ratio of albumin to gamma globulin was very marked, however. ${ }^{8}$

The results when albumin was taken orally are about what is to be expected. Albumin contains only $0.2 \%$ tryptophane and $1.7 \%$ isoleu-

\begin{tabular}{|c|c|c|c|}
\hline & M.S. & D. F. & $\begin{array}{l}\text { Healthy medical } \\
\text { students }\end{array}$ \\
\hline $\begin{array}{l}\text { Total protein } \\
\text { Albumin (crystalline) } \\
\text { Gamma globulin } \\
\text { Albumin/gamma globulin } \\
\text { Albumin/total protein }\end{array}$ & $\begin{array}{l}74 \\
26 \\
1.0 \\
26 \\
37\end{array}$ & $\begin{array}{l}53 \\
38 \\
1.4 \\
27 \\
72\end{array}$ & $\begin{array}{l}25-38 \mathrm{mgm} \% \\
11-19 \mathrm{mgm} \% \\
1.7-3.8 \mathrm{mgm} \% \\
5-8.8 \\
38-53 \%\end{array}$ \\
\hline
\end{tabular}

cine (12), and therefore it fails to support growth when fed to young rats (25). The minimal daily human requirements of these amino acids when embodied in a whole protein of high digestibility are $0.4 \mathrm{gm}$ and $1.2 \mathrm{gm}$ respectively (26). Even though supplemented with $3 \mathrm{gm}$ of DL-acetyltryptophane, $75 \mathrm{gm}$ of albumin supplies scarcely enough isoleucine. It is therefore not surprising that one of the two subjects fed this amount was in negative balance, and that negative balance resulted from oral feeding of $35 \mathrm{gm}$ in Experiment I and of $50 \mathrm{gm}$ in Experiment III. In contrast, the utilization of intravenous albumin suggested by the potassium retention in Experiments II and IV might be explained by specific biological properties of the undigested, whole albumin molecule. The reservaton must be made, however, that the albumin employed has been somewhat altered by its processing and the 10 -hour pasteurization to which it is submitted. How such alterations may affect its metabolic behavior it is not possible to say.

In general, the results of these experiments, presented previously (27) in a preliminary report, are in agreement with those of the prior workers in albumin metabolism. The phenomena of cardiovascular overloading had been encountered heretofore by Waterhouse, Bassett, and Holler (24), Watson and Greenberg (28), and Faloon and co-workers (29), although not to such a severe extent in any subjects of established good health. It is clear that such complications seriously limit the usefulness of very large amounts of albumin for nutritional purposes. The catabolization of albumin had been demonstrated by Albright and associates (9) and Waterhouse and colleagues (24), employing the assumption that increases in urinary nitrogen over the baseline output may be attributed to breakdown of the added dietary constituent (albumin). The conversion of albumin into protoplasm had been suggested by the same two groups of workers, based on positive phosphorus and potassium balances. In the present study, the minimal intake of potassium during the period of intravenous albumin was designed to permit recognition of small increments in urinary potassium output, and so did not afford sufficient potassium for positive balance to occur. However, the marked positive potassium balances in the following control pe- 
riods of Experiments II and IV we believe to have the same significance as had they occurred during the period of intravenous albumin administration. We regard the evidence of cellular uptake of potassium as suggestive of albumin conversion into protoplasm, but lacking in finality.

\section{SUMMARY AND CONCLUSIONS}

1. When human serum albumin supplemented with DL-acetyltryptophane is infused in normal subjects, large amounts of albumin accumulate in the plasma, the interstitial fluid, and the lymph. Albuminuria commonly develops.

2. As larger quantities of albumin accumulate, increasing amounts are catabolized, as demonstrated by rising urinary nitrogen and sulfur. If albumin is administered for a sufficient time, the urinary nitrogen will equal the infused albumin nitrogen. (Experiments I and IV.)

3. The evidence in these experiments for synthesis of protoplasm from the albumin is a strongly positive potassium balance in the period following intravenous albumin administration. More definite verification is desirable. (Experiments II and IV.)

4. When albumin supplemented with DL-acetyltryptophane is taken by mouth, quantities less than $75 \mathrm{gm}$ are insufficient to give nitrogen equilibrium. (Experiments I and III.) Of two subjects receiving $75 \mathrm{gm}$, one was in equilibrium and the other was in negative nitrogen balance. (Experiments II and IV.)

5. Congestive heart failure may develop in healthy young males receiving as little as $50 \mathrm{gm}$ of albumin intravenously daily for one week. Considerable care must be exercised in administering albumin to patients with low circulatory reserve and to those who have no albumin deficiency. The phenomena of circulatory overloading seriously hamper the usefulness of albumin as a nutritional supplement, beyond its well-established value in making up actual deficits of serum albumin.

\section{ACKNOWLEDGMENT}

Grateful acknowledgement is made to Drs. William Jeffers, Harry Vars, Otto Rosenthal, Isaac Starr, and James Walker, Jr. for assistance and advice during the experiments. Admiration is expressed for the subjects, Dr. James Nixon and Mr. Melvin Sobel. We thank Miss Marie Barnes and Miss Helen Harvey, who helped throughout the project. Miss Florence Halpern, Miss Mary Hannigan and Mrs. Peggy R. Beatty rendered technical assistance.

\section{BIBLIOGRAPHY}

1. Daft, F. S., Robscheit-Robbins, F. S., and Whipple, G. H., Plasma protein given by vein and its influence upon body metabolism. J. Biol. Chem., 1938, 123, 87.

2. Holman, R. L., Mahoney, E. B., and Whipple, G. H., Blood plasma protein given by vein utilized in body metabolism; a dynamic equilibrium between plasma and tissue proteins. J. Exper. Med., 1934, 59, 269.

3. Elman, R., and Davey, H. W., Studies on hypoalbuminemia produced by protein-deficient diets. III. The correction of hypoalbuminemia in dogs by means of large plasma transfusions. J. Exper. Med., 1943, 77, 1.

4. Terry, R., Sandrock, W. E., Nye, R. E., Jr., and Whipple, G. H., Parenteral plasma protein maintains nitrogen equilibrium over long periods. J. Exper. Med., 1948, 87, 547.

5. Thorn, G. W., Armstrong, S. H., Jr., Davenport, V. D., Woodruff, L. M., and Tyler, F. H., Chemical, clinical, and immunological studies on the products of human plasma fractionation. XXX. The use of salt-poor concentrated human serum albumin solution in the treatment of chronic Bright's disease. J. Clin. Invest., 1945, 24, 802.

6. Thorn, G. W., Armstrong, S. H., Jr., and Davenport, V. D., Chemical, clinical and immunological studies on the products of human plasma fractionation. XXXI. The use of salt-poor concentrated human serum albumin solution in the treatment of hepatic cirrhosis. J. Clin. Invest., 1946, 25, 304.

7. Janeway, C. A., Gibson, S. T., Woodruff, L. M., Heyl, J. T., Bailey, O. T., and Newhouser, L. R., Chemical, clinical, and immunological studies on the products of human plasma fractionation. VII. Concentrated human serum albumin. J. Clin. Invest., 1944, 23, 465.

8. Meyer, F. L., Hirshfeld, J. W., Abbott, W. E., Pilling, M. A., Williams, H. H., and Richards, A. J., Nitrogen balance and blood volume studies in man during and following repeated plasma transfusions. Am. J. M. Sc., 1947, 213, 160.

9. Albright, F., Forbes, A. P., and Reifenstein, E. C., Jr., The fate of plasma protein administered intravenously. Tr. A. Am. Physicians, 1946, 59, 221.

10. Eckhardt, R. D., Lewis, J. H., Murphy, T. L., Batchelor, W. H., and Davidson, C. S., Chemical, clinical and immunological studies on the products of human plasma fractionation. XXXIV. Comparative studies on the nutritive value of orally and intravenously administered human serum albumin in man. J. Clin. Invest., 1948, 27, 119. 
11. Reifenstein, E. C., Jr., Albright, F., and Wells, S. L., The accumulation, interpretation, and presentation of data pertaining to metabolic balances, notably those of calcium, phosphorus, and nitrogen. $J$. Clin. Endocrinol., 1945, 5, 367.

12. Brand, E., Kassell, B., and Saidel, L. J., Chemical clinical, and immunological studies on the products of human plasma fractionation. III. Amino acid composition of plasma proteins. J. Clin. Invest., 1944, 23, 437.

13. Shohl, A. T., Mineral Metabolism, Chapter 8. Reinhold Publishing Co., 1939.

14. Drinker, C. K., The formation and movements of lymph. Am. Heart J., 1939, 18, 389.

15. Chibnall, A. C., Rees, M. W., and Williams, E. F., Total nitrogen content of egg albumin and other proteins. Biochem. J., 1943, 37, 354.

16. Meeker, E. W., and Wagner, E. C., Titracion of ammonia in presence of boric acid. Indust. \& Engin. Chem. (Analyt. Ed.), 1933, 5, 396.

17. Ormsby, A. A., A direct colorimetric method for the determination of urea in blood and urine. J. Biol. Chem., 1942, 146, 595.

18. Fiske, C. H., The determination of inorganic sulfate, total sulfate, and total sulphur in urine by the benzidine method. J. Biol. Chem., 1921, 47, 59.

19. Hald, P. M., Flame photometer for measurement of sodium and potassium in biological materials. $\mathrm{J}$. Biol. Chem., 1947, 167, 499.

20. Koch, F. C., and McMeekin, T. L., A new direct nesslerization micro-Kjeldahl method and a modification of the Nessler-Folin reagent for ammonia. J. Am. Chem. Soc., 1924, 46, 2066.
21. Howe, P. E., The determination of proteins in blood -A micro method. J. Biol. Chem., 1921, 49, 109.

22. Kabat, E. A., Glusman, M., and Knaub, V., Quantitative estimation of the albumin and gamma globulin in normal and pathologic cerebrospinal fluids by immuno-chemical methods. Am. J. Med., 1948, $4,653$.

23. Gibson, J. G., II, and Evelyn, K. A., Clinical studies of the blood volume. IV. Adaptation of the method to the photoelectric microcolorimeter. J. Clin. Invest., 1938, 17, 153.

24. Waterhouse, C., Bassett, S. H., and Holler, J. W., Metabolic studies on protein-depleted patients receiving a large part of their nitrogen intake from human serum albumin administered intravenously. J. Clin. Invest., 1949, 28, 245.

25. Hegsted, D. M., May, A. L., and Stare, F. J., Chemical, clinical, and immunological studies on the products of human plasma fractionation. XXIV. Studies on the nutritive value of human plasma fractions. J. Clin. Invest., 1945, 24, 657.

26. Harte, R. A., and Travers, J. J., Human amino acid requirements. Science, 1947, 105, 15.

27. Riegel, C., and Gimbel, N. S., Utilization of human serum albumin injected intravenously. Federation Proc., 1949, 8, 242.

28. Watson, C. J., and Greenberg, A., Certain effects f saltpoor human albumin in cases of hepatic disease. Am. J. M. Sc., 1949, 217, 651.

29. Faloon, W. W., Eckhardt, R. D., Murphy, T. L., Cooper, A. M., and Davidson, C. S., An evaluation of human serum albumin in the treatment of cirrhosis of the liver. J. Clin. Invest., 1949, 28, 583. 